\title{
Strategi Komunikasi Digital Influencer dalam Menggunakan Media Sosial Instagram sebagai Media Fundraising
}

\author{
Andia Elfika Priselie ${ }^{1}$, Sinta Paramita ${ }^{2 *}$ \\ ${ }^{1}$ Fakultas Ilmu Komunikasi Universitas Tarumanagara \\ Email: andia.915170140@stu.untar.ac.id \\ ${ }^{2}$ Fakultas Ilmu Komunikasi Universitas Tarumanagara* \\ Email: sintap@fikom.untar.ac.id
}

Masuk tanggal : 15-12-2021, revisi tanggal : 06-01-2022, diterima untuk diterbitkan tanggal : 16-01-2022

\begin{abstract}
In the current era of globalization, fundraising or fundraising can be done in various interesting ways. With the existence of the internet media, fundraising can be done with a wider reach. Through Instagram social media, fundraising has proven to be more effective. The entry of the Covid-19 virus in Indonesia has encouraged influencers in Indonesia to take fundraising actions using their personal Instagram accounts. The purpose of this research is to find out how the digital communication strategy used by influencers in using Instagram as a fundraising medium. This research was conducted because there was no research that discussed digital communication strategies in using social media Instagram as a media for fundraising. The theory used in this research is communication strategy theory, communication technology, new media, and effective communication. The research used a descriptive qualitative approach with a case study research method. The research data were obtained from in-depth interviews and documentation of the five key informants. The research result states that an unique content $t$ does not always attract the attention of the audience, but the most important thing is how the message is told correctly and easily understood.
\end{abstract}

Keywords: digital communication strategy, fundraising, influencer, Instagram, social media

\begin{abstract}
Abstrak
Di era globalisasi sekarang, penggalangan dana atau fundraising dapat dilakukan dengan berbagai cara menarik. Dengan adanya media internet, proses penggalangan dana menjadi lebih mudah dan dapat mencangkup banyak lapisan masyarakat. Melalui media sosial Instagram, fundraising terbukti lebih efektif. Masuknya virus Covid-19 di Indonesia membuat influencer-influencer di Indonesia terdorong untuk melakukan aksi fundraising menggunakan akun Instagram pribadinya. Tujuan penelitian adalah untuk mengetahui bagaimana strategi komunikasi digital yang digunakan oleh influencer dalam menggunakan Instagram sebagai media fundraising. Penelitian ini dilakukan karena belum ada penelitian yang membahas mengenai strategi komunikasi digital dalam menggunakan media sosial Instagram sebagai media fundraising. Teori yang digunakan dalam penelitian ini adalah teori strategi komunikasi, teknologi komunikasi, media baru, dan komunikasi efektif. Penelitian menggunakan pendekatan kualitatif deskriptif dengan metode penelitian studi kasus. Data hasil penelitian diperoleh dari hasil wawancara mendalam dan dokumentasi dari lima key informan. Hasil penelitian menyatakan bahwa konten yang dibuat sangat unik tidak selalu menarik perhatian khalayak, namun yang terpenting adalah bagaimana pesan diceritakan dengan benar dan mudah dipahami.
\end{abstract}

Kata Kunci: fundraising, influencer, Instagram, media sosial, strategi komunikasi digital 


\section{Pendahuluan}

Di era globalisasi sekarang, penggalangan dana atau fundraising dapat dilakukan dengan berbagai cara menarik. Dengan adanya media internet, proses penggalangan dana menjadi lebih mudah dan dapat mencangkup banyak lapisan masyarakat. Melalui media sosial Instagram, fundraising terbukti lebih efektif dan mendapat dukungan yang luar biasa dari masyarakat.

Dengan menggunakan media sosial, penggalangan dana terhitung lebih mudah, murah, dan efektif. Jangkauan yang lebih luas mendorong masyarakat untuk mendukung penggalangan dana ini. Seperti yang kita tahu bahwa media sosial kini tidak dapat dipisahkan dari masyarakat, hampir semua lapisan masyarakat di Indonesia menggunakan media sosial. Terutama untuk mencari informasi, memberikan informasi, dan berbagai bentuk komunikasi lainnya.

Internet dapat memberikan kemudahan bagi seseorang untuk berpartisipasi dalam program fundraising atau penggalangan dana karena penyampaian informasi melalui media sosial akan lebih mudah dan cepat, selain itu juga dapat tersebar lebih luas. Sehingga orang-orang yang sedang membutuhkan bantuan, akan segera terbantu dengan mudah. Media sosial sangat berperan penting dalam kehidupan manusia. Media sosial berfungsi untuk menyebarkan informasi melalui interaksi sosial dan dirancang dengan penyampaian yang menarik dan mudah diakses (Wiliammson dalam Widjajanto, 2013).

Di Indonesia, pengguna media sosial sangat tinggi jumlahnya karena kemudahan dalam penggunaannya, selain itu juga hemat biaya dan efektif. Banyaknya pengguna aplikasi instagram melakukan kampanye mengenai kemanusiaan ataupun kegiatan fundraising. Terutama yang dilakukan oleh artis atau influencer Indonesia pada masa sekarang ini. Selain media sosial Instagram, ada beberapa media sosial lainnya yaitu youtube, twitter, dan facebook juga dapat digunakan untuk media fundraising. Dengan kemudahan dalam menggunakan media sosial, membuat beberapa orang terbantu karena mereka hanya perlu berdonasi melalui telepon genggam mereka yang terhubung dengan internet, tanpa harus mendatangi lokasi donasi tersebut (print kompas.com).

Media sosial membantu masyarakat yang sedang membutuhkan bantuan menjadi lebih cepat mendapatkan bantuan dari orang lain. Donatur dan calon donatur akan lebih mudah mendapatkan informasi dengan lengkap dan jelas melalui telepon genggam mereka. Donatur pun tidak perlu datang ke tempat korban yang membutuhkan bantuan, mereka hanya perlu melakukan bantuan menggunakan jempol mereka. Media sosial membuat semua menjadi lebih mudah dan efektif.

Strategi komunikasi menurut digunakan untuk melakukan persuasi yang bertujuan membangun pemahaman khalayak terhadap suatu ide atau gagasan. Strategi komunikasi ini biasanya dilakukan dengan tujuan mencapai sesuatu yang diinginkan. Pace dan Faules merumuskan 5 faktor penting dalam strategi komunikasi yaitu: (1) Tentukan tujuan komunikasi; ketika ingin melakukan sesuatu, haruslah dimulai dengan menentukan tujuan, sehingga proses komunikasi menjadi terarah dan memiliki tujuan yang jelas. Pahami bahwa tujuan melakukan komunikasi adalah untuk memberikan informasi atau mendapatkan informasi. Selain itu, proses komunikasi juga dapat dilakukan untuk mempengaruhi atau mempersuasi seseorang agar melakukan sesuatu sesuai dengan yang diharapkan oleh komunikator atau organisasi.

(2) Segmentasi khalayak; setelah menentukan tujuan komunikasi, langkah selanjutnya adalah melakukan segmentasi. Segmentasi utama yang dilakukan adalah dengan 
menentukan siapa khalayak yang dituju. Mulai dari jenis kelamin, usia, domisili, tingkat pendidikan, tingkat perekonomian, dan sebagainya. (3) Penyusunan dan Metode Penyampaian Pesan; selanjutnya tidak kalah pentingnya, yaitu dengan menentukan tema pesan yang disampaikan, setelah itu menyusun pesan dengan efektif dan menarik sehingga mudah dimengerti oleh khalayak umum.

Ada dua metode penulisan pesan, yang pertama bersifat one side issue dan yang kedua both side issue. One side issue adalah pesan yang berfokus atau menitikberatkan pada satu hal. Pesan hanya berisi tentang pemahaman komunikator tanpa melihat pendapat yang ada di masyarakat. Sehingga one side issue ini lebih terkesan satu arah saja. Sedangkan both side issue merupakan pesan yang berfokus pada dua arah, yaitu dari sisi komunikator dan dari sisi khalayak. Sehingga pesan berisi konsepsi yang ingin disampaikan komunikator dan juga berisi apa yang sedang berkembang di masyarakat. (4) Pemilihan Media; setelah semua hal mengenai pesan sudah dikemas dengan baik.

Langkah selanjutnya adalah memilih media mana yang tepat untuk menyampaikan informasi yang kita miliki. Pemilihan media dalam strategi komunikasi ini dipilih sendiri oleh komunikator, karena komunikatorlah yang tahu persis media mana yang cocok untuk menyampaikan pesan yang ia miliki. (5) Peranan Komunikator; dalam proses komunikasi, komunikator menjadi bagian terpenting karena komunikatorlah yang mengiringi suatu pesan atau informasi agar strategi komunikasi menjadi berhasil.

Beberapa hal yang dinilai penting oleh khalayak adalah tingkat kredibilitas sumber dan daya tarik yang dimilikinya. Agar pesan dapat diterima sepenuhnya oleh khalayak, maka kredibilitas dari komunikasi menjadi faktor yang penting. Ada dua unsur kredibilitas seseorang, yaitu: keahlian dan dapat dipercaya. Seseorang akan menerima suatu pesan karena beranggapan bahwa komunikatornya memiliki kredibilitas yang tinggi atau keahlian dibidangnya. Kredibilitas ini berujung pada kepercayaan masyarakat. Sehingga sebagai seorang komunikator juga harus dapat dipercaya. Komunikator harus dapat membangun kepercayaan khalayak dengan menyampaikan pesan yang benar adanya dan dapat diverifikasi kebenarannya.

\section{Metode Penelitian}

Penelitian kualitatif adalah jenis penelitian yang pengumpulan datanya melalui instrument kuni atau pengalaman peneliti selama melakukan penelitian. Penelitian ini tidak diperoleh melalui hitungan statistik. Penelitian kualitatif merupakan penelitian secara deskriptif. Pada penelitian ini hasil penelitian dijabarkan melalui kata-kata dan bahasa. Peneliti menggunakan penelitian kualitatif agar dapat meneliti secara mendalam mengenai strategi komunikasi digital influencer dalam menggunakan media sosial instagram sebagai media fundraising.

Penelitian ini menggunakan metode penelitian studi kasus dimana peneliti mengangkat suatu kasus untuk mengetahui strategi komunikasi yang digunakan oleh Influencer di Instagram dalam menjalankan fundraising.

Subyek penelitian dalam penelitian ini adalah infuencer yang melakukan fundraising menggunakan akun Instagramnya seperti Fellexandro Ruby, Rudi Valinka, Faishal Anzhar, Cecillia Octavia. Sedangkan objek dalam penelitian ini adalah media sosial Instagram dari masing-masing influencer yaitu@fellexandro@tetapkurawa @faishalazhr@cecillocta. 
Data hasil penelitian diperoleh dari hasil observasi, wawancara, studi dokumentasi, dan penelusuran data online. Wawancara dilakukan secara langsung dan menggunakan aplikasi zoom dengan beberapa narasumber. Fellexandro Ruby, Rudi Valinka, Faishal Azhar sebagai key informan dalam penelitian ini. Selain itu juga wawancara dengan Cecillia Octavia sebagai informan pendukung.

\section{Hasil Temuan dan Diskusi}

Pada bagian ini penulis akan merumuskan hasil penelitian yang diperoleh berdasarkan hasil wawancara mendalam dan observasi kesesuaian hasil wawancara dengan tangkapan layar (screenshot) akun Instagram key informan.

\section{Pemilihan Strategi Komunikasi Media Sosial}

Fellexandro Ruby sempat melakukan aksi fundraising pada awal pandemi yaitu pada bulan April untuk membantu para tenaga kesehatan di beberapa rumah sakit. Ia mendapat kabar dari temannya yang berprofesi sebagai dokter mengenai kondisi rumah sakit dan tenaga kesehatan yang sangat memprihatinkan. Oleh sebab itu ia tergerak untuk melakukan fundraising.

Strategi komunikasi digital yang dilakukan Ruby dalam Instagramnya adalah dengan membuat postingan tentang hasil screenshot perbincangan mengenai kondisi rumah sakit dengan temannya yang berprofesi sebagai dokter, dengan bermodalkan screenshot tersebut, Rudy menjalankan Selanjutnya setelah donasi terkumpul, ia menggunakannya untuk membeli APD dan masker medis yang dibagikan ke rumah sakit di Jakarta, Tangerang, Bekasi, Sumbawa, dan Sulawesi.

Pada saat mendistribusikan ke berbagai rumah sakit, ia memastikan bahwa penerimanya adalah dokter-dokter yang sudah ia hubungi terlebih dahulu dan berfoto bersama hasil donasinya. Langkah selanjutnya adalah dengan selalu mengunggah foto donasi yang sudah diterima oleh pihak rumah sakit.

Strategi yang ia lakukan ternyata berjalan dengan sangat baik karena kurang dari 24 jam, Ruby dapat mengumpulkan lebih dari 60 juta yang ia alokasikan untuk pembelian ribuan APD dan puluhan ribu masker medis. Dalam wawancara, Ruby menyebutkan bahwa ia hanya membuka donasi selama 1 hari karena ia tidak ingin menyimpan uang hasil fundraising terlalu lama karena banyak tenaga kesehatan yang membutuhkan peralatan medis tersebut secara cepat. Ruby juga membuat tagar \#FriendsFellexandro dalam aksi fundraising tersebut.

Sementara itu Rudi Valinka yang prihatin dengan kondisi tenaga kesehatan di Indonesia yang sangat kekurangan alat-alat kesehatan, ingin memberikan contoh kepada orang banyak dalam menggunakan media sosial untuk hal positif seperti mengadakan fundraising.

Kata Rudi, lebih baik bertindak dibanding teriak-teriak kritik tapi diam di rumah. Ia telah melakukan fundraising mulai dari awal virus Covid-19 masuk ke Indonesia sampai sekarang. Hasil donasi yang diperoleh telah mencapai lebih dari 30 miliar. Aksi donasi tersebut ditujukan kepada berbagai rumah sakit di Indonesia dan telah membantu lebih dari 300 rumah sakit di Indonesia.

Rudi mendonasikan alat-alat kesehatan, seperti masker, APD, hand sanitizer, bahkan sampai peti mati. Target utama dari rumah sakit yang mendapatkan donasi adalah rumah sakit rujukan karena merawat pasien covid secara gratis, kemudian rumah sakit milik pemerintah (RSUD) dan yang terakhir rumah sakit umum biasa. 
Strategi komunikasi digital yang dilakukan oleh Rudi Valinka adalah dengan menggandeng beberapa artis dan kaum sosialita untuk bersama melakukan aksi fundraising tersebut yang dipublikasikan pada akun pribadi masing-masing artis dan influencer.

Selanjutnya, ia menyatakan bahwa yang terpenting adalah bagaimana kita dapat menceritakan suatu pesan agar mudah dipahami oleh masyarakat. Dengan menceritakan kejadian yang terjadi saat itu kepada audience maka akan menarik lebih banyak perhatian apalagi disertakan dengan foto-foto pendukung.

Selain itu, ketika melakukan fundraising melalui media sosial, harus dilakukan secara konsisten dan mengunggah bukti donasi secara terus menerus untuk mengambil trust (kepercayaan) followers atau para donatur. Ia juga menggandeng kitabisa.com agar khalayak lebih percaya karena dapat melihat secara transparan berapa hasil donasi yang diperoleh. Dengan sistem fundraising yang sangat terstruktur inilah yang menghasilkan banyak sekali donatur-donatur dan volunteer yang ingin membantu dalam fundraising yang diadakan oleh Rudi Valinka.

Faishal Azhar punya cara yang berbeda, ia ikut melakukan aksi fundraising untuk membantu para pencari nafkah yang terkena langsung dampak dari Corona ini. Ia bekerjasama dengan organisasi @youthranger.id dan Yayasan Terangi Hujan pada 14 Mei lalu.

Strategi Komunikasi yang digunakan oleh Faishal Azhar dalam menggunakan Instagram untuk melakukan fundraising adalah dengan memberikan informasi selengkap dan sejelas mungkin tentang detail dari organisasi yang bekerjasama untuk penggalangan dana tersebut. Ia tidak dengan secara langsung meminta followersnya untuk berdonasi, namun menanamkan mindset terlebih dahulu bahwa organisasi yang bekerjasama dengan Faishal merupakan organisasi yang memiliki visi yang baik. Ia menganggap bahwa hal terpenting dalam fundraising adalah building trust para followers atau calon donaturnya.

Selanjutnya, Faishal juga mengunggah konten yang menunjukkan bahwa ia ikut berdonasi. Menurutnya hal tersebutlah yang meningkatkan kepercayaan followersnya sehingga ingin ikut berdonasi. Agar pesan yang disampaikan oleh Faishal menarik bagi followersnya, ia mencoba menggunakan hashtag \#1orang1porsi. Maksudnya adalah dengan orang berdonasi, ia dapat adil dalam memberikan 1 porsi makan kepada masyarakat yang membutuhkan.

Faishal juga menyatakan bahwa tujuan dari fundraising tersebut tidak sematamata hanya untuk membantu masyarakat yang terkena dampak langsung dari Covid19 , namun ia juga ingin membuktikan dan mengajak anak-anak muda bahwa anak muda juga dapat andil secara langsung dalam aksi sosial seperti ini. Menurutnya, masih sangat minim anak muda yang ingin melakukan atau turun tangan secara langsung dalam aksi sosial salah satunya seperti fundraising.

Beda pula dengan Cecillia Octavia. Perempuan yang akrab dipanggil Cecil nitu mengaku sudah sering mengadakan aksi fundraising, bahkan sebelum ada Covid-19 pun, cecil sering berkunjung ke panti-panti asuhan untuk memberikan donasi yang sudah ia kumpulkan.

Kini alasan dia untuk melakukan fundraising untuk tenaga kesehatan di rumah sakit NTT karena mengetahui bahwa rumah sakit di daerah masih banyak sekali yang tidak terkena bantuan dari pemerintah terlebih ia tahu karena kakaknya tinggal disana. oleh sebab itu, Cecil dan kakak perempuannya bersama melakukan aksi penggalangan dana. Mereka membagi tugas yaitu, Cecil mengurus segala donasi di Jakarta sampai 
pengiriman, sedangkan kakaknya mengurus hasil donasi dan mendistribusikan donasi tersebut secara adil.

Cecil menyatakan bahwa donasi ini tidak bekerja sama dengan siapa pun, ini adalah pure keinginan Cecil dan kakaknya. Strategi komunikasi digital yang dilakukan oleh Cecilia Octavia adalah dengan mengunggah hasil-hasil donasi yang diterima setiap harinya agar menarik perhatian dari followersnya.

Cecil mengatakan pentingnya ada poster, karena poster dapat disebarkan melalui media sosial maupun secara langsung. Oleh sebab itu, poster donasi harus didesain sebaik mungkin agar menarik perhatian followers.

Sebagai catatan, Fellexandro Ruby telah memperkenalkan dirinya di Instagram sejak 2017. Ia dikenal melalui podcast nya "Thirty Days of Lunch". Ruby mengatakan bahwa Instagram sangat membantu dia menciptakan branding tentang dirinya. Ia konsisten membagikan ilmu-ilmu yang ia dapatkan kepada followers Instagramnya, dan kini followers Ruby mencapai 85,4 ribu followers. Ia juga mengatakan bahwa dengan kepercayaan yang ia miliki dari followersnya itu yang membuat semakin mudah aksi fundraising yang ia lakukan. Dikenal sebagai orang yang simple, ia menggunakan Instagram untuk melakukan fundraising juga dengan cara yang sangat sederhana.

Sementasra itu Rudi Valinka mulai menggunakan Instagram pada tahun 2016. Namun sebenarnya ia tidak terlalu aktif di Instagram karena namanya memang sudah dikenal oleh warga Twitter. sehingga ia lebih aktif dalam menggunakan media sosial Twitter. Namanya semakin terkenal sejak kasus yang menimpa Basuki Tjahaja Purnama (Ahok), karena Rudi membuat buku "A Man Called Ahok". Walaupun tidak terlalu aktif di Instagram, Rudi memiliki 25,3 ribu followers.

Mengenai Faishal Azhar, ia memulai karirnya pada tahun 2018. ia mulai menggunakan Instagram sejak 2012, namun mulai aktif menggunakan Instagram sebagai influencer sejak tahun 2019. Ia mempunyai 13,8 ribu followers. Awal mula ingin melakukan aksi donasi adalah karena temannya yang merupakan pendiri dari @ youthrangers.id meminta bantuannya untuk membantu fundraising tersebut.

Dengan adanya media sosial, kini semua menjadi serba mudah. Maka dapat disimpulkan bahwa media sosial terutama Instagram membawa banyak keuntungan dan kemudahan dalam melakukan fundraising.

\section{Pengemasan Pesan dalam Media Sosial}

Hasil wawancara dengan Fellexandro Ruby menyebutkan bahwa dengan mengenal khalayak atau followersnya harus saling melakukan interaksi, membaca komentar dan membalas komentar yang ditanyakan oleh followersnya. Dengan melakukan hal tersebut, maka Ruby dapat mengenal tipe-tipe followersnya sehingga ia mengerti apa yang harus ia lakukan agar suatu pesan atau kegiatan yang ingin dia lakukan dapat tersampaikan dengan baik kepada followers.

Pada wawancara yang saya lakukan dengan Ruby, ia mengatakan bahwa followersnya termasuk unik karena tidak ada yang mempertanyakan sama sekali fundraising yang ia adakan, namun mereka berdonasi secara langsung tanpa basa-basi. Ia merasa senang karena sangat dipercaya oleh para followersnya. Selanjutnya adalah pesan yang ia sampaikan sangat sederhana dan tidak bertele-tele. Ia meringkas suatu pesan dengan bahasa sehari-hari sehingga lebih mudah masuk kepada followersnya.

Pesan yang Ruby sampaikan dikemas dengan sangat sederhana dan tentu saja berdasarkan kondisi yang sedang terjadi, sehingga memang sudah terbukti kebenarannya. Ia juga mengatakan bahwa membuat design seperti poster donasi dan 
sebagainya tidak sepenuhnya efektif, karena ia membuktikan dengan hanya bermodal screenshot pesan bersama temannya, dan ditambahkan dengan caption yang sesuai, itu lebih efektif menarik perhatian followersnya dan mendapatkan banyak donasi hanya kurang dari 1 hari.

"Sebenarnya banyak sekali orang yang mau berdonasi, namun mereka tidak tahu harus berdonasi kemana dan tidak tahu harus percaya pada siapa. Makanya ketika saya mengumumkan bahwa saya terdorong untuk membantu teman-teman tenaga kesehatan disitulah personal branding saya masuk yang membuat banyak sekali teman-teman dan followers yang mau berpartisipasi," kata Fellexandro Ruby.

Oleh sebab itu, personal branding sangat penting karena berhubungan dengan reputasi atau citra diri dari influencer. Jika sudah mendapatkan kepercayaan dari khalayak maka personal branding yang dimiliki oleh influencer tersebut pastilah positif.

Agar fundraising berjalan efektif, pesan yang disampaikan oleh Ruby pun dikemas dengan sangat menarik. Ia membuat perumpamaan sederhana yang dapat dipahami dengan mudah oleh followersnya. Pada saat donasi ia tidak menyebutkan nominal yang dibutuhkan, melainkan ia memberi contoh bahwa dengan Rp 100.000 anda dapat menyelamatkan berapa nyawa, contoh lain adalah dengan tidak ngopi sehari anda dapat menyambung hidup berapa banyak orang. Dan itulah yang membuat mindset dari followersnya menjadi terbuka dan ikut berdonasi.

Sementara itu Rudi Valinka mengatakan bahwa strategi komunikasi adalah bagaimana seseorang meringkas suatu pesan atau kejadian menjadi sebuah cerita yang mudah dimengerti oleh banyak orang dan bagaimana menjadi "storyteller" yang benar.

Menurutnya, dunia ini sangat membutuhkan seorang story teller karena bila sebuah kisah dapat diceritakan dengan benar maka orang dapat mengerti suatu pesan dengan baik. Sebuah pesan yang disampaikan dengan benar dan ditambah dengan gambar atau foto-foto yang memang sedang terjadi di lapangan dapat menjadi pesan yang sangat berdampak.

Hasil dari wawancara dengan Faishal Azhar dan Cecilia Octavia menyatakan bahwa membuat poster atau pesan donasi yang menarik dapat menarik perhatian followers, Namun yang terpenting adalah bagaimana awal memulai aksi fundraising tersebut. Tidak semata-mata hanya untuk mendapatkan donasi dari followersnya namun dengan memberikan informasi-informasi mendalam mengenai apa yang sedang terjadi secara detail. Dengan memposting setiap kegiatan donasi juga penting karena untuk menumbuhkan rasa kepercayaan dari masyarakat dan para donatur, Cecil membuat sebuah video singkat dari hasil donasi yang ia peroleh sampai dengan diterima oleh pihak-pihak rumah sakit di NTT. Video tersebut jelas membuktikan bahwa donasi yang diperoleh benar-benar terdistribusi dengan baik. Cecil menambahkan bahwa personal branding yang dibuatnya di Instagram juga penting dalam hal fundraising ini, karena memang sudah sering melakukan fundraising maka banyak orang yang sudah percaya terhadap dirinya.

Dari hasil wawancara yang penulis lakukan dengan 4 orang key informan, bahwa keterkaitan antara teori dan hasil wawancara yang dilakukan oleh penulis adalah strategi komunikasi digital influencer dalam menggunakan media sosial Instagram sebagai media fundraising.

Penulis merangkum bahwa strategi komunikasi yang digunakan oleh para key informan hampir sama yaitu dengan mengenal audiencenya, menarik kepercayaan dari audiencenya, membuat pesan yang menarik namun mudah dipahami, dan yang 
terakhir adalah konsisten dalam memberikan bukti-bukti nyata proses fundraising tersebut.

\section{Simpulan}

Penulis merangkum beberapa kesimpulan dari hasil penelitian yang dilakukan penulis sebagai berikut

1. Key informan sebagai influencer menggunakan Instagram sebagai media fundraising karena penggunaannya yang lebih mudah dan lebih mendapat banyak donasi dari pada media sosial lainnya.

2. Dengan memposting setiap jumlah donasi di akun pribadi para influencer adalah cara untuk membuktikan bahwa fundraising tersebut benar adanya.

3. Menarik perhatian dari followers dengan memberikan informasi serta pesan yang mudah dipahami.

4. Membuat perencanaan yang matang pada saat ingin melakukan fundraising

5. Mengenal audiencenya menumbuhkan rasa percaya audiencenya, dan membuat pesan yang menarik namun mudah dipahami, konsistensi adalah poin penting dalam fundraising melelui media sosial.

\section{Ucapan Terima Kasih}

Peneliti ingin mengucapkan terima kasih kepada Fakultas Ilmu Komunikasi Universitas Tarumanagara, narasumber, serta semua pihak yang turut membantu peneliti sehingga penelitian ini dapat diselesaikan.

\section{Daftar Pustaka}

Nasrullah, Rulli. (2015). Media Sosial Perspektif Komunikasi, Budaya dan Sosioteknologi. Bandung: Simbiosa Rekatama Media

Sugiyono. 2014. Metode Penelitian Pendidikan Pendekatan Kuantitaf, Kualitatif, dan $R \& D$. Bandung: Alfabeta.

Widjajanto, Kenmada. (2013). Konsep dan Aplikasi Perencanaan Komunikasi. Bandung: Ultimus. 